\title{
Abhandlung
}

Uri Gabbay* and Sam Mirelman*

\section{Text and Performance: Tayyartu, "Repetition," in a Mīs Pî-Type Incantation and an Emesal Prayer}

DOI 10.1515/za-2017-0003

\begin{abstract}
The following examines the Akkadian scribal annotation tayyartu, "return," demonstrating that it refers to a repetitive section of a text that was not copied by the scribe. Editions of two texts where this annotation occurs, a Mīs Pî-type incantation and an Emesal prayer, are included. In addition, the phenomenon of repetition and abbreviation in incantations and Emesal prayers is briefly discussed.
\end{abstract}

\section{Introduction}

The noun tayyartu, "return," can be used as a scribal annotation. ${ }^{1}$ Reiner/Pingree $(1975,8$ f.) suggested that in such a context the noun refers to textual repetition. In the following article we will examine the occurrences of this noun in this context and demonstrate that it is used as a shorthand to refer to repetitive sections of compositions in performance that were not written in full by the scribe. The two examples presented here are found in two hitherto unpublished tablets: a Mīs Pî-type incantation from Nineveh and a LB Emesal fragment, probably from Babylon, both from the British Museum. ${ }^{2}$

1 See CAD T, 59b, para. 4. Our rendering of the form follows AHw, 1303b (tajjartu(m)) rather than CAD T, 58f. (tajārtu). For the issue of whether the second $a$-vowel is long or short, see $\mathrm{GAG}^{3} \S 550^{\star}$; Huehnergard (1997, 442); Kouwenberg (1997, 61-63).

2 Besides the two clear attestations of the scribal annotation tayyartu dealt with in this article there are two other attestations of the noun tayyartu that may refer to the same scribal annotation, although these are uncertain (note that the reference by Reiner/Pingree

Article Note: Abbreviations are according to CAD, except for CDLI = http://cdli.ucla.edu. We are grateful to Enrique Jiménez and Paul Delnero for many useful remarks, suggestions, and references, and to Walther Sallaberger and Antoine Cavigneaux for their important editorial suggestions and corrections. K.5246+, K.5309, and BM 48485 are published by permission of the Trustees of the British Museum.

*Corresponding authors: Uri Gabbay, Department of Archaeology and Ancient Near East, Hebrew University of Jerusalem, Jerusalem, Israel, E-mail: gabbay.uri@mail.huji.ac.il

Sam Mirelman, Institute for the Study of the Ancient World, New York University, New York, USA, E-mail: sam.mirelman@nyu.edu
In the case of the Mīs Pî-type incantation published below, the term tayyartu refers to the performance of a section shared also by a separate incantation (a g a ma h "Exalted crown"), which the scribe did not deem necessary to be written out in full. The term tayyartu is also used in a clearly performative context, in a LB fragment published here, containing a prayer in Emesal, probably

[1975, 9 n. 5] to tayyartu in the astrological commentary Rm. 932: 3'-6' [see also CAD R, 59b, para. 4] does not seem to have the meaning "repetition," but due to its occurrence with išû and rašû seems to be a citation of an apodosis of an omen followed by a re-citation with commentary, and may refer to "(divine) forgiveness" [cf. CAD R, 59a]; similarly their reference to tayyartu as a feature on the exta is probably not related to repetition [CAD T, 59b, para. 3]): (1) Two similar subscripts in the so-called Venus Tablet of Ammișaduqa (Enūma Anu Enlil 63) occur at the end of the Tablet (Reiner/Pingree 1975, 60: $\mathrm{S}_{7}$ $\left.\mathrm{S}_{8}\right): 2 / 4$ ? ki-iș-ru ša dnin-si $i_{4}-a n-n a$ a-ḩu-tu ${ }_{4}$ TA ŠÀ ki-iṣ-ri ta-a-a-ar-ta (var. $t a-a-a-r a-t u_{4}$ ) ina š̀̀-bi. This formula was interpreted by Reiner/ Pingree (1975, 8f.) as referring to omens that occurred earlier in the Tablet and are repeated here too. An earlier, similar, rubric, contains the similar word tāmurātu, "visibilities" (Reiner/Pingree 1975, 47: $\mathrm{S}_{2}$ ). Reiner/Pingree (1975, 8 n. 3) provide contextual support for the understanding of tāmurātu as a variant of tāmarātu, but Borger (apud Reiner/Pingree 1975, 8 n. 3) suggests to see it as a variant of tayyartu and tayyarātu, "repetition(s)," in the other rubrics, by reading the sign MU as $i a_{5}$, i. e., $t a-i a_{5}-r a-t u_{4}$. This may indeed be correct, but one may also wonder whether the evidence could point to the opposite direction, namely that $t a-a-a-a r-t a, t a-a-a-r a-t u_{4}$ are writings for tāmar $(\bar{a}) t u\left(>{ }^{\star} \operatorname{ta} w a r(\bar{a}) t u>\operatorname{ta} y a r(\bar{a}) t u\right)$, "visibility, visibilities," and that the word tayyartu, "repetition," actually does not occur here at all. (2) A lipšur litany from Nineveh (Reiner 1956, 144-146) contains the noun tayyartu (lines 29-30): [a]-mat-su še-ma-a-tu ' $q \hat{\imath}$ '-bi-is-su ma-ag-ra-tu 4 li-paț-rak-ku pi-š̀rr-t[i?] / [(x)] x-ul lìb-bi líp-țúr-ku ki-iṣ-ri $t a-a-a-a r-t[i]$. The interpretation of these lines is very difficult, and it cannot be ascertained whether tayyartu is a scribal annotation (as interpreted in CAD T, 59b) or part of the text (perhaps in apposition to kișrî?). 
a Balaĝ prayer. The term appears in this tablet with the common phrase referring to skipped lines of repetitive litanies. Its appearance with this phrase is exceptional, and may be an explicit reference to the way such repetitive sections were regarded. The performative nature of this Emesal fragment is supported by the inclusion of vocalic performative indications, which are well known in LB copies of Emesal prayers (Mirelman 2010).

These two instances are of particular interest, not only for their rarity, but also due to the fact that they provide an insight into the performance practices of the repertoires of both the kalû and the ăšipu. Indeed, these texts provide rare evidence of a shared terminology, and by extension, elements of a shared performance practice, between the two most important practitioners of sung and recited prayers in ancient Mesopotamia.

\section{Repetition, abbreviation and performance in incantations and Emesal prayers}

Mesopotamian incantations and Emesal prayers generally represent performed utterances, whether spoken, declaimed or sung. This claim is beyond doubt, due to the abundance of available information concerning the ritual context of the performance of such compositions, at least for the first millennium BCE. ${ }^{3}$ However, the textual representation of such compositions, or in other words, the relationship between the physical text and the performance of the composition represented by the text, cannot be assumed to correspond precisely. Various forms of abbreviation are used to indicate that lines or sections of compositions are omitted from the manuscript of such compositions, but must be included in performance. The purpose of writing tablets which include such extensive abbreviations, whether they belong to the repertoire of the kalû or the $\bar{a}$ šipu, must lie in their function as aidemémoires. ${ }^{4}$ In addition, there are indications or suggestions in manuscripts of incantations and prayers, which point towards a non-linear performance of the text. Thus,

3 For studies on the performative aspects of incantations, see, e.g. Maul (1994, 39-156) and Jean (2006). For recent overviews on the performative aspects of Emesal prayers, see Löhnert (2009, 55-61); Gabbay (2014a, 155-190), both with previous literature.

4 See Maul (1994, 203f.): "Die Namburbi-Kompendien waren nur für einen Beschwörer von Nutzen, der die Ritualtexte auswendig beherrschte und den Text der Tafel lediglich als Gedankenstütze benötigte." the performance may include repetitions within the text which are not written out fully; alternatively, the performance of sections may follow an order which differs from the textual order. The written text may be considered as material which is used for performance, according to conventions of performance practice. Such performance practices are occasionally specified in explicit form, although they may also be suggested indirectly.

One of the most detailed texts which inform us regarding the performance of Emesal prayers in the OB period, is the Eštar ritual from Mari (Durand/Guichard 1997; Ziegler 2007, 55-64). The ritual specifies the performance of specific sections (kirugus) of the Balaĝ úru àm-ma-ir-ra-bi, at specific points during the ritual action. It appears that the accompanying Eršema, the name of which is not specified, is not performed following the Balaĝ; instead, it is interpolated within the kirugus of the Balaĝ úru àm-mair-ra-bi (Cavigneaux 1998). This feature is indicative of the non-linear use of texts in performance. Indeed, similar practices of referring to incipits of sections of Emesal texts, within ritual texts, is known in the first millennium BCE (Gabbay 2014a, 174-176). Generally, however, OB Emesal manuscripts suggest a performative context of production and use, implicitly rather than explicitly. ${ }^{5}$

In a few LB Emesal tablets, one finds the noun mihru (written: mi-hir), "antiphony," paired with performative indications or with phrases occurring in the main text of the composition (Gabbay 2014a, 83). This may refer to the singing of an element from the composition, perhaps by a different kalû or perhaps even a choir of kalûs, outside of its textual sequence, perhaps repeated at several points during the performance.

Repetition of entire compositions is sometimes specified in first millennium BCE ritual instructions for the performance of Balaĝ and Eršema prayers, and some OB Emesal tablets may indicate the repetition of entire sections (Gabbay 2014a, 177, 188f.). In first millennium BCE incantations, repetition of the entire composition is often specified in the accompanying ritual instructions or rubrics; for example, incantations are often specified to be repeated seven times (CAD S, 204) or three times (CAD Š/I, 235).

The repetition of formulaic lines within a passage is often indicated in first millennium Emesal manuscripts by the annotation MU.MEŠ GU ${ }_{4}$ UD.MEŠ "skipped lines," refer-

5 Such suggestive features in OB manuscripts include, for example, the fact that most OB Emesal manuscripts are known in single copies, which exhibit significant variants amongst known duplicates; in addition, the use of syllabic writings suggests their probable use for rehearsal and/or performative purposes (Delnero 2015). 
ring to the textual omission of repetitive litanies of thirty lines or more (Mayer 1990, 32 f.). A precusor of this practice is known from the scribal annotation ilu adi iggammarū "the gods, until they are complete" in an OB Emesal prayer (Cohen 1988, 280: e+174), indicating that a long list of gods, occurring in many prayers, is omitted from the tablet (Löhnert 2009, 52f.).

Another type of abbreviation for repeated refrains or repeats, which includes only partial variations for each line, consists of only the first few signs of a given line, or half line, followed by a blank space. This form of abbreviation is widespread in the Emesal corpus; it is less common in incantations, although examples are known (e.g. in Šurpu III and IV, for which see Reiner 1958, 2; or Maqlû IV, for which see Abusch 2015, 245 f.).

In the context of magical rituals, repeated phrases may be written in an abbreviated form. For example, the phrase lippațrūnikku lippašrūnikku "let them be released for you, let them be absolved for you!" known from Lipšur litanies, may be abbreviated to lip : lip (Reiner 1956, 131). Additionally, in first millennium BCE manuscripts of incantations, the typical Marduk-Ea dialogue is normally abbreviated to the opening and closing lines, of what in its full form may extend to approximately fifteen lines (Falkenstein 1931, 57; Geller 2016, 28, with n. 51). Such opening and/or closing lines themselves, may also be abbreviated in such contexts (e.g. Geller 2016, 251: 9'). Turning to the repertoire of the bārû-diviner, in tāmitu oracle queries to the gods Šamaš and Adad, the last passage is usually abbreviated, alluded to only by the writing of the first word kiam "thus" (Lambert 2007, 18 f.).

Abbreviation is not only used in the context of repetition, but also of summarization. In an OB manuscript of an Emesal prayer to Inana, written in a highly phonetic orthography (VS 2, 94), only the beginnings of every line are written. The latter part of each line is omitted, as shown by blank (not broken) space on the right side of the tablet, and by a comparison of this tablet with a parallel manuscript where the lines are written in full (VS 2, 95). ${ }^{6}$ A summarizing feature of first millennium BCE manuscripts of Emesal prayers is the writing of tablets which include only key lines - mostly incipits of kirugus, but also extracts of other lines - and which condense such compositions to a skeleton outline (Gabbay 2014a, 232f.).

6 See the discussion of this tablet by Delnero $(2015,109)$. An edition of these tablets is in preparation by P. Delnero, whom we thank for sharing photographs of VS 2, 94 with us. In addition, there are a few examples of $\mathrm{OB}$ tablets containing Emesal prayers in which the text is not written on the tablet to its end, which may be explained as an abbreviation related to the performance of the text; see Delnero $(2016,81)$.
Such tablets can be clearly demonstrated to be summaries when compared to full length versions of the same compositions. The practice of summarizing tablets, although in a somewhat different way, can be traced back to the middle of the second millennium, as shown by an Emesal manuscript attributed to the First Sealand Dynasty (Gabbay 2014b). ${ }^{7}$

Abbreviation may also take place on the level of ritual instruction. Such abbreviations, termed "compendia" in the case of summary tablets of Namburbi rituals (Maul 1994, 203-216), and "memoranda" in the case of rituals against Lamaštu and other magical contexts, ${ }^{8}$ feature the abbreviation of ritual actions to key elements, whilst associated incantations are referred to by incipit only.

Another example of abbreviation is known from the standard sequence of incantations, recited at the end of rituals or ritual sections, when surrounding the patient's bed with an apotropaic circle of flour. The full set of this standard sequence is attested in the Muššu'u ritual tablet (Böck 2003, 6), but it is known from other contexts as well, such as Maqlû and Lamaštu. Indeed, the sequence was standardized to the extent that an abbreviated instruction for its performance seems to be specified in at least one instance (ÉN $a$-nam-di ÉN adi(EN) ÉN $t$ [ummu bìtu] “(you recite) the incantation 'I have cast a spell' up to and including the incantation ' $A$ [djured is the house]'”; see Abusch/ Schwemer 2011, $397 \mathrm{f}$.). The same notion is also suggested by the fact that in the ritual tablet of Maqlû the incipits of these incantations are given, although the full texts are omitted from the incantation tablets (Abusch 1974, $254 \mathrm{f}$.).

The omission of Akkadian translations is a form of abbreviation which is especially common in repeated litanies, or otherwise repetitive sections. Thus, in the Mīs Pî-type incantation below, it is significant that from line $8^{\prime}$ onwards, precisely from the line at which the tayyartu scribal marking appears (in text A), manuscript B changes

7 This phenomenon may be traced earlier still, if we include the example of VS 2, 94 mentioned above. Mention may also be made of OB tablets of Sumerian royal inscriptions, and literary texts which reduce compositions to their opening lines. Presumably, such tablets were written as mnemonic aids within a pedagogic context, although their precise function is unclear (Civil 1985, 37-45; Geller/Johnson 2015, 27-29). Another case of abbreviation worth mentioning is a tablet from Isin containing Sumerian literary compositions in a highly abbreviated form (Wilcke 1987, 85-89; reference: P. Delnero). Lastly, as noted to us by P. Delnero, lexical and grammatical abbreviations are already found in Early Dynastic III literary compositions, again indicating that the written text was used for mnemonic reasons; see Delnero (2012, 92).

8 Schwemer (2006); Abusch/Schwemer (2011, Texts 7.6.6 and 8.7); for such summary tablets in magical texts, see Schwemer (In Press, section 3.4. "Diplomatische Systematik"). 
from a bilingual to a monolingual (Sumerian) text. This monolingualism also applies to the parallel manuscript for this formulaic section (Ht B below).

\section{A Mīs Pî-type incantation}

The following composition is an incantation related to the induction of the divine cult image, the Mìs Pî ritual, perhaps for one of the ritual objects to be used for the cult of the divine image. ${ }^{9}$ The incantation is preserved in two tablets from Nineveh written in Neo-Assyrian script, K.5246+K.5678 (Text A) and K.5309 (Text B). According to the scribal note in the last line of Text A, the last portion of the text, not copied by the scribe of the tablet, contains the same formulaic passage (tayyartu, "repetition") as in the incantation a g a mah, "Exalted crown," the first incantation in Mīs Pî V (Walker/Dick 2001, 193-195). This passage is preserved in Text B. Indeed, the passage preserved in Text B parallels the beginning of the latter part of the incantation "Exalted crown." Additionally, the passage preserved in Text $B$ parallels the beginning of the latter part of the incantation ŝišg $\mathrm{u}-\mathrm{za}$ k ù - g a, "Holy throne," the incantation that follows "Exalted crown" in Mīs Pî V (Walker/Dick 2001, 195-198). Lines 8'-14' of our incantation share parallel lines with these incantations. However, our incantation cannot be identified as belonging to either of these incantations. Lines $1^{\prime}-7^{\prime}$ of our incantation clearly do not parallel relevant lines of the incantations "Exalted crown" (Walker/Dick 2001, $194 \mathrm{f}$., Section A: 13-15) or "Holy throne" (Walker/Dick 2001, 196f., Section B: 17-26). Thus, our incantation is closely related to Mīs Pî V, although its identification remains uncertain.

Although Text A seems to refer to the entire rest of the incantation from this point on as repeating the rest of the incantation "Exalted crown," ${ }^{10}$ it is likely that after the first duplicating lines (preserved in Text B) there was some variation. Although the immediately following passage is not preserved in the "Exalted crown" incantation, the final lines of this incantation specifically refer to the crown (Walker/ Dick 2001, 195, Section B: 1-6, esp. 2-3), and it is likely that our incantation either changed the word "crown" with the

\footnotetext{
9 We would like to thank the participants of the Cuneiforum at the University of Würzburg, on the $12^{\text {th }}$ May, 2016, for their helpful comments on the reading of this incantation.

10 Since a dividing line and probably an empty space follow the annotation, it is likely that the tablet did not contain the continuation of the composition, and perhaps only had a colophon. However, since this part is broken, one cannot exclude the possibility, that the text resumed for the final passage of the incantation.
}

word for the subject of the incantation within the same formulas, or used different formulas. A similar pattern is observable in the "Holy throne" incantation. After the first lines duplicating our incantation and the "Exalted crown" incantation, the text refers specifically to the foundations of the throne (Walker/Dick 2001, 197, Section B: 29-30), which is not likely to have occurred in the two other incantations. The following section of the "Holy throne" incantation, too, seems to differ from the "Exalted crown" incantation. ${ }^{11}$ Therefore we assume that the repetitive formulaic (tayyartu) section refers to the following passage preserved in Text B, but from there on until the end of the incantation, at least some variation occurred.

Both the "Exalted crown" incantation and the "Holy throne" incantation were to be recited together, according to the Mīs Pî Ritual Tablets, before beginning a procession from the garden at the riverbank back to the cella. ${ }^{12}$ It is possible that the tablets edited here, therefore, contain the closing lines of one of the other two incantations that are prescribed in the Ritual Tablets with "Exalted crown" and "Holy throne" during the same cultic context. Thus, it

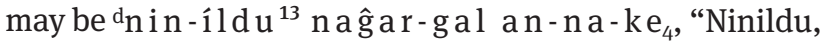
great carpenter of Heaven,” or túg mah túg-níĝ lám-ma gada babbar-ra, "Exalted garment, splendid garment of white linen."

The incantation "Exalted garment, splendid garment of white linen" is most probably preserved in Mīs Pî V as the incantation following "Exalted crown" and "Holy throne," ${ }^{14}$ and it would not be surprising if these three consecutive incantations, recited in the same cultic context, shared a common passage. Consequently, the incantation edited below may perhaps be identified as containing the incantation "Exalted garment." Note especially line 3' of

11 See Walker/Dick (2001, $197 \mathrm{f}$., Section B: 31-40). It cannot be excluded though, that the missing lines in Section B: 34-37 (Walker/ Dick 2001, 198) corresponded to lines in Section B: 1-2 (and probably earlier unpreserved lines) of the "Exalted crown" incantation (Walker/Dick 2001, 195), and that this was followed by the formulaic purification ending (Walker/Dick 2001, 195, Section B: 3-6; 198, Section B: 38-40).

12 See Nineveh Ritual Tablet: 187-194, and Babylonian Ritual Tablet: 53-56 (Walker/Dick 2001, 51, 66 f., 73, 76, 80 f.).

13 Our transliteration follows the standard rendering of this divine name. There is evidence, though, that indicates the reading ${ }^{d} n$ in dúl u m (Cavigneaux/Krebernik 1998-2001, 340).

14 Walker/Dick (2001, 198f.). The beginning of the incantation, including the incipit, is not preserved. Nevertheless, the rubric following the incantation (Walker/Dick 2001, 199, Section C: 10: kainim-ma túgsíg diĝir-ra ka-luh-ù-da-kam, "Incantation for the mouth washing [ritual] for the wool garment of a god") indicates that the identification of the preserved text with the end of the incantation "Exalted garment" is most probably correct. 
our composition which probably mentions the dressing in a pure garment, which would fit the incipit of this incantation. ${ }^{15}$

As noted above, another incantation was to be recited in the same ritual context as the incantations "Exalted crown," "Holy throne," and "Exalted garment," namely, the incantation "Ninildu, great carpenter of Heaven." This incantation is not preserved in Mīs Pî V (and hitherto unidentified in any of the other tablets). Perhaps our composition should be identified with it. The incipit of the incantation would seem to refer to a wooden object, perhaps the cult statue itself, whose various features are described in the incantation, such as its dressing (line $3^{\prime}$ in our incantation) and the offering brought to it on the offering table (line 6'). Alternatively, the incantation could have referred to a wooden cultic object, perhaps a portable offering table (see line $6^{\prime}$ ) which could have been carried with the god (adorned with a crown and a garment, and sitting on a portable throne, as indicated by the other three incantations), in a procession to the cella.

As noted, the incantation "Ninildu, great carpenter of Heaven" is not known from Mīs Pî V. It is possible that although it is mentioned in the Ritual Tablets it was not part of the Mīs Pî series of incantations. Alternatively, it may have been part of the series but not identified yet. There is some inconsistency in the organization of the last tablets of the Mīs Pî series. Thus, the incipit of the incantation é-sír-ra du-a-ni-ta, "As he walked down the street," serves as the catchline found at the end of Tablet V, but also at the end of Tablet VII. Therefore, the tablet consisting of the incantation "As he walked down the street" may be identified as either Tablet VI or Tablet VIII of Mīs Pî. ${ }^{16}$ The only evidence for Tablet VII is K.6031 (CT 17, 40),

15 However, the last (and only) preserved lines of the incantation "Exalted garment" differ from the last lines of the incantation "Exalted crown" (except for the last 3-4 formulaic lines; see Walker/Dick 2001, 195, Section B: 1-6, and 198-199, Section C: 1-9), which would not be in keeping with the scribal note in Text A of our composition. Nevertheless, as noted above, it is likely that this scribal note refers to the middle part of the incantation, and that the last lines were not repeated in Text A even though they were different. Thus, it is still possible that our composition is part of the incantation "Exalted garment." (The first preserved line of the "Exalted garment" incantation [Walker/Dick 2001, 198, Section C: 2] of which only the signs ku r - r a can be identified, does not seem to be identical with kur-kur-ra towards the end of the formulaic passage in our incantation [see line $12^{\prime}$ ], the "Exalted crown" incantation [restored], and the "Holy throne" incantation [see the score transliteration below], since the continuation is different.)

16 See Walker/Dick (2001, 31, 210). Unless there were two different incantations sharing the same incipit, as is the case with the incantation ĝen-na na-an-gub-bé-en, known in three versions (all in Mīs Pî IV); see Walker/Dick (2001, 156); Shibata (2008). which contains a standard ending line of an unidentified incantation, ${ }^{17}$ its rubric, ${ }^{18}$ the catchline to the incantation "As he walked down the street," and a remark that it is the seventh tablet of Mīs Pî. ${ }^{19}$ It is possible that the incantation "Ninildu, great carpenter of Heaven," and the incantation preserved in our text, whether identical with each other or not, were preserved in this tablet. ${ }^{20}$

\section{Edition}

The two tablets containing our incantation are distinct, both in terms of their writing style and their content. Text $B$ is written in a cursive, rapidly executed script, where some of the sign forms are readable only from context. By contrast, Text A, which skips the section included in Text B using the tayyartu formula, is carefully written in a typical Assurbanipal-library hand.

As noted above, the formulaic (tayyartu) section that begins in line 8' occurs in the "Exalted crown" and "Holy throne" incantations as well. The relevant lines from these incantations are given in small typeface within the score of our incantation, with the sigla Ec and $\mathrm{Ht}$, referring to the "Exalted crown" and "Holy throne" incantations, respectively. The passages from these two incantations are

17 Line 1': 'li-šáa-nu le-mut-tú ina a-ḩa'-[ti li-iz-ziz].

18 Line 2': ka-inim-ma iri-a kù [...].

19 Lines $3^{\prime}-4^{\prime}$. See Walker/Dick (2001, 210, n. 1).

20 The inconsistency in the sequence of the tablets may be related to an inconsistency regarding the arrangement of the incantations in Tablets IV and V vis-à-vis the setting of the performance of these incantations in the Ritual Tablets. The incantations "Exalted crown," "Holy throne," "Ninildu, great carpenter of Heaven," and "Exalted garment, splendid garment of white linen," are performed according to the passages in the Ritual Tablet before the procession heads back to the temple (see above with n. 12). This probably implies that the cultic image was adorned with his crown and clothing, and seated on a (portable) throne at this point, and not in the temple. However, while Tablet IV begins with incantations preceding the four incantations mentioned above according to the Ritual Tablets (Walker/Dick 2001, 66: 188-190; 76: 53-54), it then skips directly to the incantations recited after these four incantations according to the Ritual Tablets, during the procession to the temple, and then contains incantations that are recited in the cella according to the Babylonian Ritual Tablet (Walker/Dick 2001, 67: 195-197; 76f.: 56-61); see Walker/Dick (2001, 156) and Shibata (2008). As discussed, Tablet V contains at least three of the four incantations mentioned above, which according to the Ritual Tablets, were recited before most of the incantations in Tablet IV, but ends with the last incantation known from the Babylonian Ritual Tablet, recited in the cella (Walker/Dick 2001, 77: 64); see Walker/Dick $(2001,192)$. This arrangement may reflect the performance of the four incantations mentioned above in the cella too, and not before the procession as in the Ritual Tablets. 
preserved on two fragments, K.4928+ and Bu.91-5-9, 207, belonging to a single tablet, K.4866+(+) from Nineveh, which contained Mīs Pî V, beginning with the "Exalted crown" and "Holy throne" incantations (Walker/Dick 2001, 192). In addition, the beginning of the last preserved line of the "Holy throne" incantation which duplicates our incantation is preserved also in another tablet from Nineveh, $\mathrm{Rm} .2$, 154, probably part of the same tablet as Sm.1694, containing Mīs Pî V as well (Walker/Dick 2001, 192).

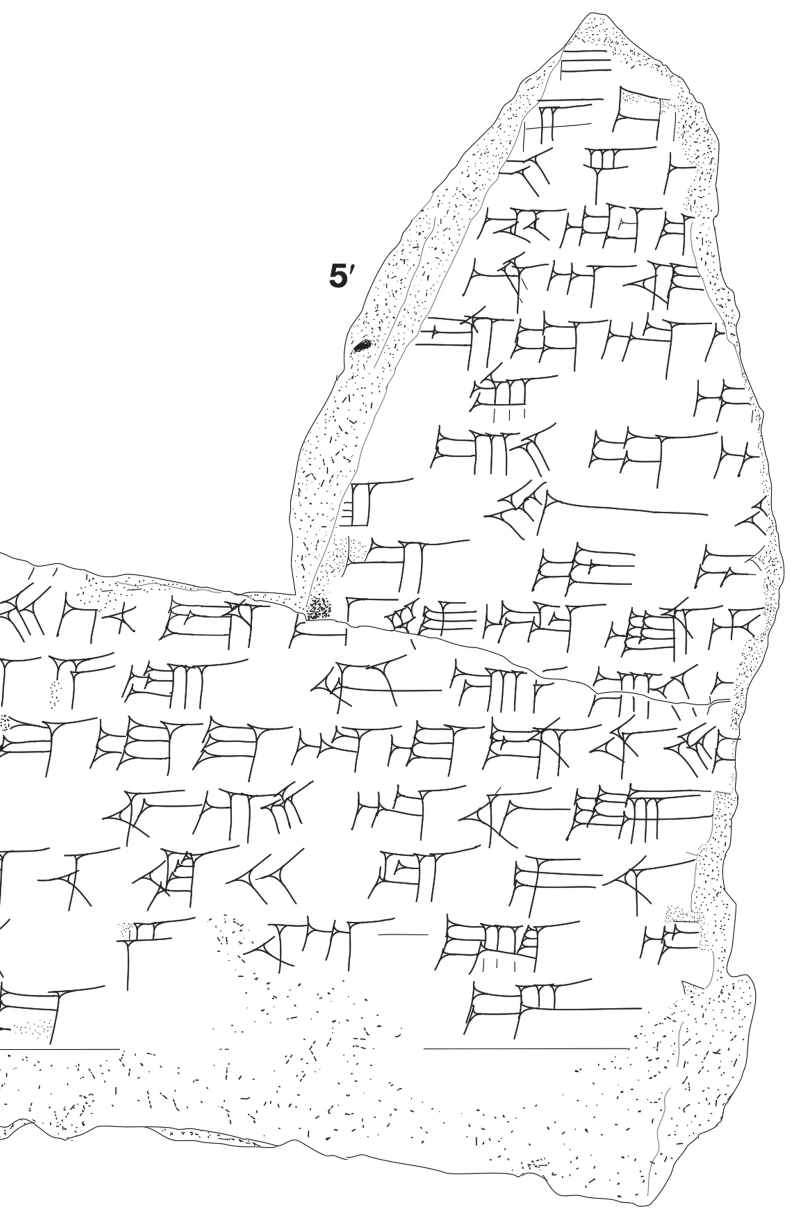

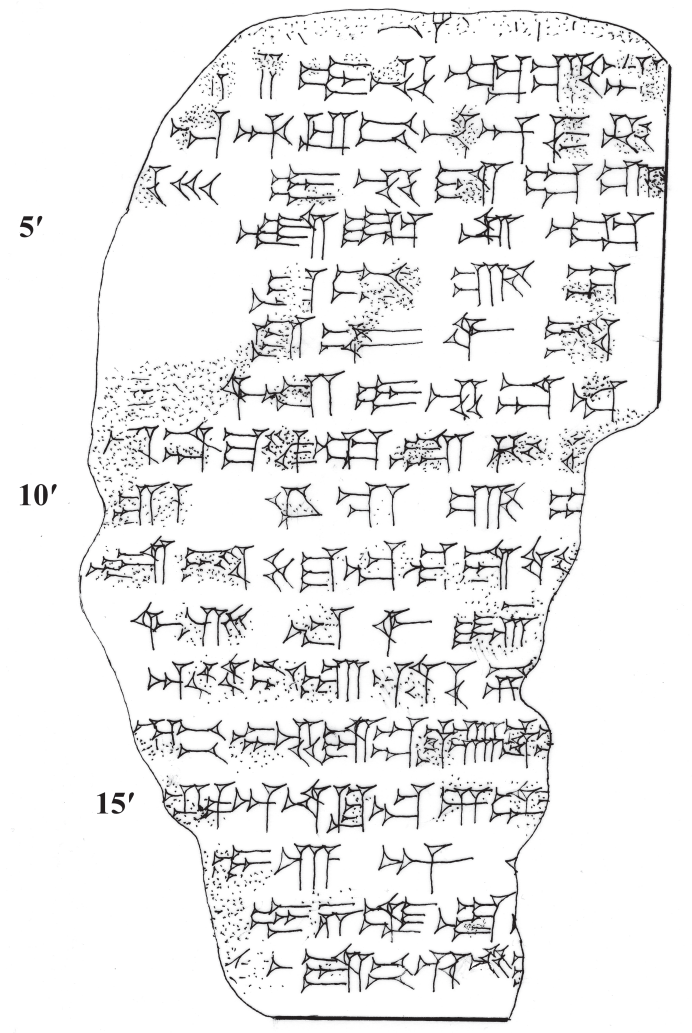

Fig. 1: $A=K .5246+K .5678$ (copy: S. Mirelman)
Fig. 2: B= K.5309 (copy: U. Gabbay)

\section{Texts}

$\mathrm{A}=\mathrm{K} .5246+\mathrm{K} .5678$ (lines $\left.1^{\prime}-8^{\prime}\right)$. Measurements: $6.5 \mathrm{~cm} \times$ $6.3 \mathrm{~cm}$ at widest. Photograph: CDLI P395953.

B = K.5309 (lines $3^{\prime}-14^{\prime}$ ). Measurements: $6.8 \mathrm{~cm} \times 4.4 \mathrm{~cm}$ at widest. Photograph: CDLI P395987.

\section{Parallels}

Ec = "Exalted crown" incantation, Mīs Pî V, Section A: 16-18, preserved in K.4928+, i 9'-15' (K.4866+(+)); see Walker/Dick (2001, 195); Borger (2005, 405); collated (// lines $\left.8^{\prime}-11^{\prime}\right)$.

$\mathrm{Ht}=$ "Holy throne" incantation, Mīs Pî V, Section B: 24-28, preserved in Bu. 91-5-9, 207, r. iii 1-11 (K.4866+(+)) and Rm. 2, 154, r. iii 1' (Sm.1694(+)); see Walker/Dick (2001, 197); Borger $(2005,406)$; collated (// lines 8'-14'). 


\section{Transliteration}

\begin{tabular}{|c|c|c|c|}
\hline \multirow[t]{2}{*}{$1^{\prime}$} & A & $0^{\prime}$ & ] \\
\hline & A & $1^{\prime}$ & ]$\times[$ \\
\hline \multirow[t]{4}{*}{$2^{\prime}$} & A & $2^{\prime}$ & ]$^{\ulcorner} \operatorname{irr}^{?]} \times[$ \\
\hline & A & $3^{\prime}$ & $b] i(-) s ̌ a ́(-) x[$ \\
\hline & $\mathrm{B}$ & $0^{\prime}$ & ] \\
\hline & $\mathrm{B}$ & $1^{\prime}$ & ] x ${ }^{\top} b i(-) \check{s} a^{\top}(-) \times \times \times$ \\
\hline \multirow[t]{4}{*}{$3^{\prime}$} & A & $4^{\prime}$ & ]- en - d $u_{11}-g[a-\quad]$ \\
\hline & A & $5^{\prime}$ & ] na-an-di-[iq] \\
\hline & $\mathrm{B}$ & $2^{\prime}$ & 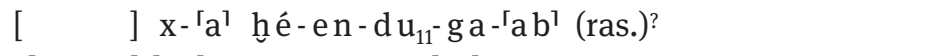 \\
\hline & B & $3^{\prime}$ & [ $\quad s ̦ u]^{-} b a^{\top}-t i$ eb-bi na-an- ${ }^{\top} d i^{\top}-i q$ \\
\hline \multirow[t]{4}{*}{$4^{\prime}$} & A & $6^{\prime}$ & hó - en-d]a-ab-ba-d[iri] \\
\hline & A & $7^{\prime}$ & $l i-s ̌ a r]-r u-k[a]$ \\
\hline & B & $4^{\prime}$ & -r]e?-eš hó-en-da-ab-diri? \\
\hline & B & $5^{\prime}$ & ] li-šar-ru-ka \\
\hline \multirow[t]{4}{*}{$5^{\prime}$} & A & $8^{\prime}$ & šu tag]-ga-ab-b[a] \\
\hline & A & $9^{\prime}$ & $l] u-p u-u[t]$ \\
\hline & B & $6^{\prime}$ & ] šu tag-ga-ab \\
\hline & B & $7^{\prime}$ & ] lu-up-pi-it \\
\hline \multirow[t]{4}{*}{$6^{\prime}$} & A & $10^{\prime}$ & 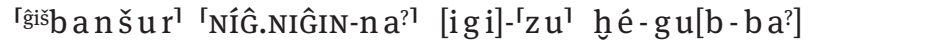 \\
\hline & A & $11^{\prime}$ & $p a-a ́ s ̌ s ̌ s u-{ }^{\top} r u^{\top}$ țuh- ${ }^{\top} h u^{\top}-d a{ }^{\top} m a^{\top}-h a r-k a$ li-i[k- \\
\hline & B & $8^{\prime}$ & ] x igi- ${ }^{\top} u^{\top}$ h é-en-gub-ba \\
\hline & $\mathrm{B}$ & $9^{\prime}$ & 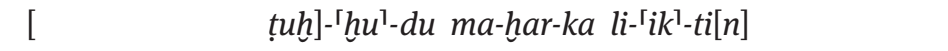 \\
\hline \multirow[t]{4}{*}{$7^{\prime}$} & A & $12^{\prime}$ & zabar zu-zu-a-ta tin diri-ga-a[b] \\
\hline & A & $13^{\prime}$ & e-le-la lit-ma-ad-ma ba-la-ța ut-ti[r] \\
\hline & B & $10^{\prime}$ & {$[\quad]^{-} \mathrm{ta}^{! ? ?}$ tin SI. $<\mathrm{A}>-\mathrm{g} \mathrm{a}-\mathrm{a}[\mathrm{b}]$} \\
\hline & B & $11^{\prime}$ & [ ] li-it-mad-ma ba-la-ța ut-t[ir] \\
\hline \multirow[t]{9}{*}{$8^{\prime}$} & A & $14^{\prime}$ & [l]ugal ú-a-ni igi zi ba-ši-in-b[ar] \\
\hline & A & $15^{\prime}$ & šar-ri za-nin-šú ki-niš ip-pa-lis-m[a] \\
\hline & B & $12^{\prime}$ & ] igi zi ba-ši-in-[bar] \\
\hline & A & $16^{\prime}$ & [t]a-a-a-ár-ti šá én aga ma[h] \\
\hline & A & $17^{\prime}$ & {$[t] u-q a t-t e-e-m a$ šID- $n[u]$} \\
\hline & A & & dividing line, space, and perhaps traces (of colophon?), then broken \\
\hline & Ec A & $16 \mathrm{a}$ & [lugal] 'úl-a-na igi zi ba-ši-in-bar \\
\hline & Ec A & $16 \mathrm{~b}$ & [ša]r-ra za-nin-šú ki-niš lip-pa- ${ }^{\lceil} l i s^{1}-m a$ \\
\hline & Ht B & 24 & ] / [ ] x x [ ] \\
\hline \multirow[t]{4}{*}{$9^{\prime}$} & B & $13^{\prime}$ & 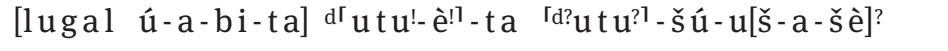 \\
\hline & Ec A & $17 a / 1$ & 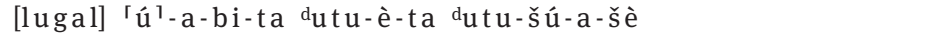 \\
\hline & Ec A & $17 \mathrm{~b} / 1$ & [ana š] ar-ri za-ni-ni-šú ul-tu și-it dUTU-ši ana e-reb ${ }^{\mathrm{d} U T U-s ̌ i ~}$ \\
\hline & Ht B & $25 / 1$ & 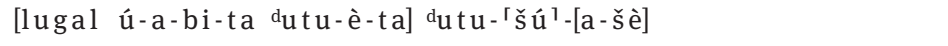 \\
\hline \multirow[t]{4}{*}{$10^{\prime}$} & $\mathrm{B}$ & $14^{\prime}$ & [gi lú- $\left.u_{18}-1 \mathrm{u}-\mathrm{ke}_{4} \mathrm{k}\right] \mathrm{A}^{?}-\mathrm{bi}{ }^{\mathrm{r}} \mathrm{h} \mathrm{e}^{1}-\mathrm{en}-\mathrm{da}-\mathrm{ab}-\mathrm{s} \mathrm{a}_{6}-\mathrm{s}\left[\mathrm{a}_{6}\right]$ \\
\hline & Ec A & $17 a / 2$ & gi lú-u $u_{18}-1 \mathrm{u}-{ }^{\top} \mathrm{ke}_{4}^{? ?} /$ KA hé-en-da-ab-sì-sì-ge-ne \\
\hline & Ec A & $17 \mathrm{~b} / 2$ & gi-mir ni-ši liš-te-mi-qa-šú \\
\hline & Ht B & $25 / 2$ & [g i lú- $\left.\mathrm{u}_{18}-\mathrm{lu}-\mathrm{ke}_{4} \mathrm{~K}\right] \mathrm{A}$ ḩé-e[n- \\
\hline \multirow[t]{3}{*}{$11^{\prime}$} & B & $15^{\prime}$ & {$\left[(\mathrm{x})\right.$ bára-bára-ke $\left.{ }_{4}-\mathrm{e}-\mathrm{ne}\right]$ ? sa ĝ? a n-na-šè ba-ni-ílb-íl?] } \\
\hline & Ec A & $18 \mathrm{a}$ & {$\left[(x)\right.$ bá]ra-bára-ke $4^{-}{ }^{\top} e^{\top}-[n e] \times x \quad x \quad[(\ldots)$ ba-ni-íb-íl] } \\
\hline & Ht B & 26 & [(x) bára-bára]-ke-e-n[e (...) sa ĝ an-šè / b]a-ni-îlb?-1́l] \\
\hline \multirow[t]{2}{*}{$12^{\prime}$} & B & $16^{\prime}$ & [ kur-kur-ra (x)] ? ' h $\mathrm{e}^{1}-\mathrm{nun}$ an(-)x-[x] \\
\hline & Ht B & $27 / 1$ & ] kur-kur-ra h[é-nun an ] \\
\hline
\end{tabular}




\begin{tabular}{|c|c|c|c|}
\hline $13^{\prime}$ & B & $17^{\prime}$ & 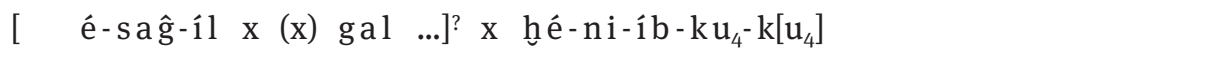 \\
\hline & Ht B & $27 / 2$ & 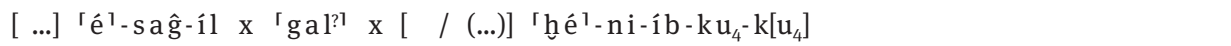 \\
\hline $14^{\prime}$ & B & $18^{\prime}$ & [lugal kur igi-nim-ma-ke ${ }_{4}$ gú]? rdugud-da-bi hul-mu-d[a?(-ab)-tùm] \\
\hline & B & & bottom; rev. not preserved \\
\hline & Ht B & 28 & 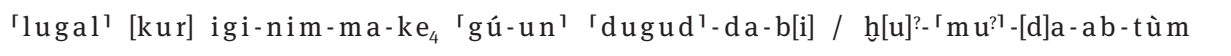 \\
\hline
\end{tabular}

\section{Translation}

$\left.\begin{array}{lll}1^{\prime} & {[} & {[\ldots[} \\ 2^{\prime} & {[} & {[\ldots[}\end{array}\right]$

Akk: Be dressed in a [... of] a clean [gar]ment!

$4^{\prime} \quad$ [ ] may they provide you plentifully!

$5^{\prime}$ Touch [ ]!

$6^{\prime} \quad$ May a lavish table be set before you!

$7^{\prime} \quad$ Be experienced in purity! Add life!

$8^{\prime} \quad$ It/he looked with steady favor upon the king, its/his provider!

Text A (instead of the following lines): You recite to its end (lit. you finish, you recite) the (formulaic) repetition of the incantation "magnificent crown."

$9^{\prime} \quad$ [Towards the king its provider], from sunrise to sunset,

$10^{\prime} \quad$ [Let all humanity] pray!

11' [The kings] rai[sed] (their) heads to the sky,

$12^{\prime} \quad$ [... of the lands, ] abundance ...

$13^{\prime} \quad$ May he/they bring into [... Esaĝil ... the great ...]!

$14^{\prime} \quad$ May [the kings of the upper land] bring their heavy [tribute]!

Rest of composition not preserved

\section{Notes}

3'. Both the Sumerian and Akkadian versions of this line pose problems. First, it is peculiar that the Sumerian h é form is translated by an Akkadian imperative, although this (rare) phenomenon does occur elsewhere as well; see Stola (1981/82, 85f.). Perhaps the unexpected ending of the verb with - ga-ab, ${ }^{21}$ resembling the suffixing of Sumerian imperative forms is what led to this understanding (see also Stola 1981/82, 86). Or perhaps the Akkadian imperative reflects an understanding of the Sumerian h he form in the second person (cf. Stola 1985, $25 \mathrm{f}$.).

As to the meaning of the verb, the verb $d u_{11}$ in the h é - form may be the verbal element of a compound form since the expected Akkadian equivalent qabû does not appear as its translation (cf. perhaps da-da-ra-š è$d u_{11}$ and $\check{e}$-er-ka-an-d $u_{11}$, which may be semantically related to the dressing in the Akkadian translation, although both are otherwise unattested with edēqu, and

21 Cf. also in the "Holy throne" incantation, Walker/Dick (2001, 196: 13): mi-ri-in-d $u_{11^{-}}$ga-ab. more importantly, do not agree with the signs before the verbal element).

If the Akkadian version is interpreted correctly, note the adjective $e b b u$ used as a designation for clean garments elsewhere as well; see CAD E, 3 a.

4'. The Akkadian verb is probably šarû, "to become rich, to prosper" in the G stem, and "to provide plentifully" in the D stem (CAD Š/II, 131f.; the verb is not well attested in the D stem). The form li-šar-ru-ka indicates a plural (unless the verbal vowel was maintained in the $\mathrm{D}$ stem as well, a rare phenomenon in SB, see GAG $\S 1051$ ), and a plural subject may be suggested by the previous - eš.

The Sumerian verb in Text B looks like KID, but is probably a deformed d i $\mathrm{i}$, as suggested also by the traces of the beginning of the last sign in Text A. Alternatively, it may turn out to be the sign kal. Both kal, "to be/make valuable," and diri, "to exceed, to be/make abundant," are semantically close to the meaning of šaru D.

The addition of - $\mathrm{ba}$ - after - $\mathrm{ab}$ - and before the verbal base in Text $A$ is peculiar, but note the addition of - ba after - ab in Text A also in line $5^{\prime}$. 
6'. See Diri V 192 (MSL 15, 174): kib-šur NÍĜ.NIĜIN = tuh-hu-du. The broken sign following NIĜIN is restored as a possible -na, but the traces also allow for -ra. The latter would be expected if the reading is indeed kibšur. The reading of the last sign in the Akkadian line is according to a suggestion by E. Jiménez.

7'. The Akkadian verb elēlu is otherwise unattested as an equivalent to Sumerian $\mathrm{zab}$ ar, but the adjective ellu is (Aa III/3 197, Diri I 128; see MSL 14, 337 and MSL 15, 108).

$\mathbf{8}^{\prime}$. The identity of the subject is uncertain here. It is likely that the subject is not a person but an object. In the incantation "Exalted crown," which shares this line with our incantation, the crown is the subject which gazes with favor at the king. In our incantation, the subject may be the cultic statue itself, or alternatively, the garment probably referred to in line $3^{\prime}$. Indeed, if the suggested identification of our incantation as "Exalted garment" is correct, the subject would most probably be the garment in this line.

The hendiadys in the scribal note in Text $\mathrm{A}$ is in keeping with other uses of quttû in hendiadyses; see CAD Q, 180 f., especially KAR 90 r. 6 // AMT 27, 4 + AMT 81, 5: 2' (Jaques 2015, 262, 267): ÉN i-lí ul i-de tu-qat-ta-ma $\mathrm{DU}_{11} \cdot \mathrm{DU}_{11}-u b$, "you recite the incantation 'My god, I do not know' to its end."

$\mathbf{9}^{\prime}-\mathbf{1 0}^{\prime}$. Note that the tablet preserving this section of the "Exalted crown" and "Holy throne" incantations treats these two lines as one line.

$10^{\prime}$. Note that the parallel line in the two other incantations does not have the ending - bi after KA. Additionally, the "Exalted crown" incantation has the verb si rather than $\mathrm{sa}_{6}$ (unpreserved in the "Holy throne" incantation). Both KA sì and KA $\mathrm{s} \mathrm{a}_{6}$ are attested for šutēmuqu; see CAD Š/III, $400 \mathrm{f}$.

$\mathbf{1 1}^{\prime}$. For this line, compare in a Nineveh copy of a bilingual dedication of a chariot by a Kassite king, IVR $212 \mathrm{r}$. $17-18:^{22}$

nam-lugal-bi bára-bára-ke-ne gú an-šè ḩé-niíb-zi-zi ...

šar-ru-us-su ina a-šib pa-rak-ki lil-li ...

May his kingship raise its neck to heaven (among) the dwellers of the daises!

22 For this text, see Stein (2000, 170-176, with previous literature), and most recently Bartelmus (2016, 507:“34”); note that a line towards the end of the "Exalted crown" incantation may be similar to another line in this bilingual dedicatory text; see Walker/Dick (2001, 195, Section B 1, with n. 11); cf. Borger (2005, 405). $12^{\prime}-13^{\prime}$. Note that the tablet preserving this section of the "Holy throne" incantation treats these two lines as one line.

14'. The first preserved sign in the line looks like Aš. However, some traces may perhaps be seen before it on the eroded surface of the tablet, which could indicate dugud as probably in the parallel (although there too, badly preserved). In any case, d u gud would fit the context of delivering a heavy (dug u d) tribute. See especially the similar phrase in a LB Sumero-Akkadian Šuila to Anu from Uruk, TCL 6, 43 r. 1-2 (Thureau-Dangin 1921, 109 r. 1-2; Linssen 2004, 197 r. 1-2; Shibata, forthcoming, no. $\left.1: 11^{\prime}\right)$ :

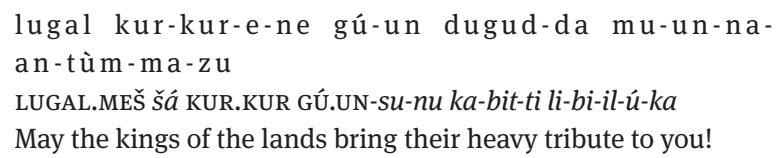

\section{A fragment of an Emesal prayer}

The LB tablet BM 48485, probably from Babylon or Borsippa, contains an unidentified Emesal prayer, probably a Balaĝ or an Eršema. Only the second parts of the lines in the obverse $\mathrm{e}^{23}$ are preserved, and they contain standard descriptions of destruction often found in Emesal prayers, although parallels or duplicates could not be identified by us. The reverse of the tablet, besides traces of a few signs, contains mostly blank lines, indicating a repetitious litany that was not written in full. A litany also occurs on the obverse of the tablet. Here, between the litany's second line and last line, written in short and leaving the end of the line empty, a scribal annotation appears in line 15', noting that twenty four lines of this litany are skipped at this point. In the present tablet the additional noun tayyartu "repetition," occurs after MU.MEš "lines," forming a genitive construction with it. Unlike the Mīs Pî-type incantation treated above, the precise function of the term tayyartu "repetition," is not explicitly specified here. However, we assume that the scribal annotation "skipped

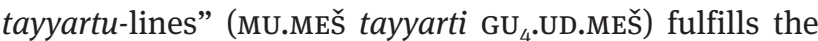
same function as the commonly attested scribal annotation "skipped lines" (MU.MEŠ GU 4 .UD.MEŠ). We assume that the inclusion of the noun tayyartu in this instance merely emphasizes the fact that the section which is omitted, is a repetition of the line appearing before this annotation

23 Even though the fragment is small, our identification of obverse and reverse is suggested by the flat surface of the obverse, and convex shape of the reverse. 
(changing only the names or epithets mentioned in it). Alternatively, the noun tayyartu may refer to the repetition of a sequence of names as in a previous litany on this tablet (although not preserved).

The skipped litany was probably that of divine names and epithets; alternatively, the litany may have consisted of toponyms, although the verb "to go" makes this possibility unlikely. A twenty-seven line litany (2 first lines + 24 skipped lines + final line) is long even by the standards of Emesal prayers. Since no divine name or toponym is preserved it is difficult to restore this litany, although the Balaĝ ukkin-ta eš bar til-la to Nabû contains a close number of lines in its litanies (Cohen 1988, $481 \mathrm{f}$. b+13-39, 486f. $d+108-136$, $490 \mathrm{f}$. $\mathrm{f}+177-203)$ and therefore perhaps this is a Nabû litany, and perhaps the current fragment should be identified as containing this Balaĝ.

\section{Edition}

BM 48485. Measurements: $6.6 \mathrm{~cm} \times 5.3 \mathrm{~cm}$ at widest.

\section{Transliteration}

Obv.

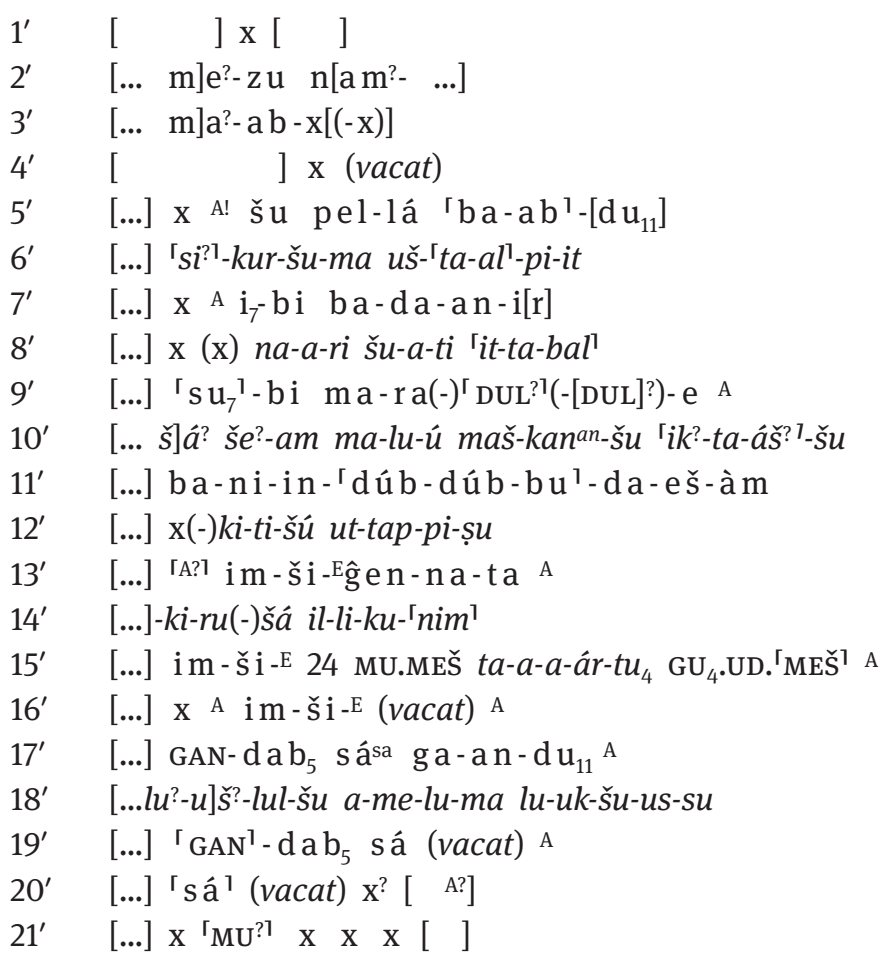

Obv. rest broken

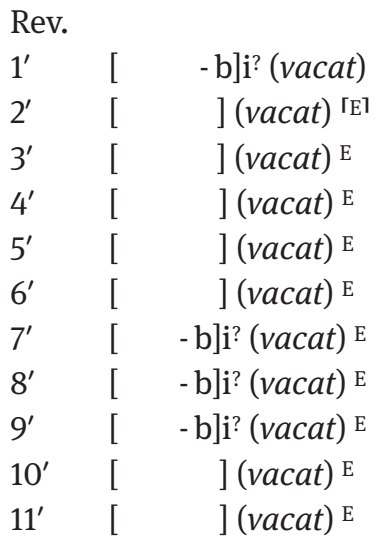




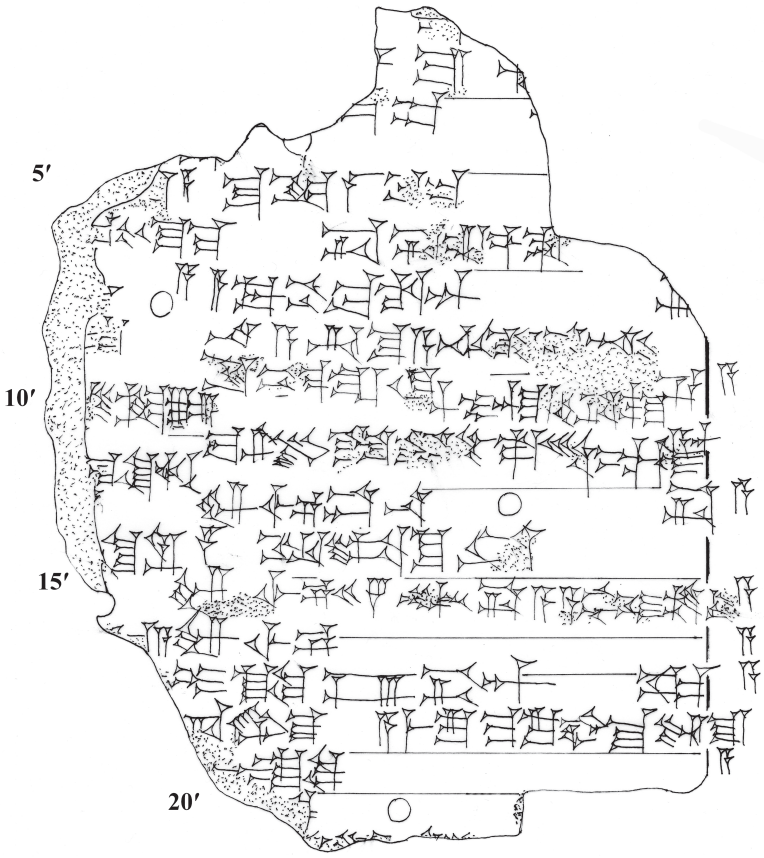

Fig. 3a: BM 48485 obverse (copy: U. Gabbay)

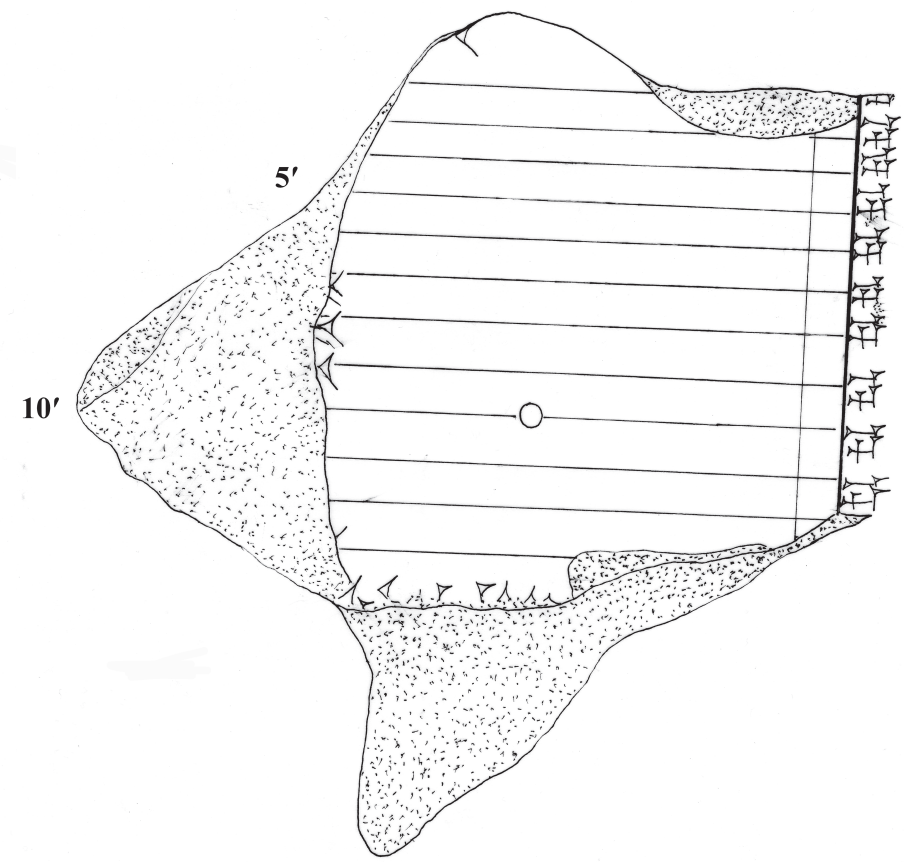

Fig. 3b: BM 48485 reverse (copy: U. Gabbay)

$12^{\prime} \quad[\quad-\mathrm{b}] \mathrm{i}$ ? (vacat) ${ }^{[\mathrm{E} ?]}$
$13^{\prime} \quad[\quad] \times x \times x(\mathrm{x})[\mathrm{]}$

Rev. rest broken

\section{Translation}

$1^{\prime}-4^{\prime} \quad$ (too broken for translation)

$5^{\prime}-6^{\prime} \quad$... its bolt, he/it was defiled.

$7^{\prime}-8^{\prime} \quad$... that river carried there.

$9^{\prime}-10^{\prime}$... [which was] full with barley, it covers its threshing floor.

$11^{\prime}-12^{\prime}$... they crushed.

$13^{\prime}-14^{\prime} \ldots$ that came.

$15^{\prime} \quad \ldots$ (that cam)e. (24 skipped lines of the repetition).

$16^{\prime} \quad$... (that cam)e.

$17^{\prime}-18^{\prime}$ [... may I take] him [into cap]tivity, may I capture the prisoner (Akk: man).

$19^{\prime} \quad$... [may I ca]pture the prisoner.

$20^{\prime}-21^{\prime} \quad$ (too broken for translation)

Rev.

(too broken for translation) 


\section{Notes}

$5^{\prime}-6^{\prime}$. The reading and interpretation of ${ }^{~} s i^{?}$ - $-k u r-s ̌ u-m a$ before the verb is uncertain. If it is correct, perhaps restore

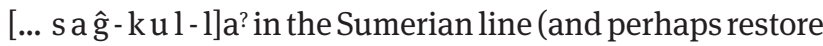
ĝiši g // daltu at the beginning of the line?). Another option is to restore $[m] a$ !?-kur-šu-ma, "its/his/her property" (for $\mathrm{mu}-\mathrm{un}-\mathrm{g} \mathrm{a}=$ makkurru, but the Sumerian line contained something after this noun). Still another possibility is that the two signs before the Akkadian verb should be understood as ŠU.MA, "ditto," indicating the same proper noun as in the Sumerian version (for ŠU.MA in Emesal prayers, see Gabbay 2015, 41). If so, perhaps read māt(KUR) šU.MA, "the land of ..." A further possibility is that the particle -ma indicates a verb, although we cannot suggest a likely restoration.

$\mathbf{9}^{\prime}-\mathbf{1 0}^{\prime}$. The reading of the first signs in the Akkadian translation, and the readings of both the Sumerian and Akkadian verbs, is uncertain. The verb kašû is otherwise not attested as an equivalent to dul (although it is not well attested in general, see CAD K, 294), but both the Sumerian and the Akkadian verbs mean "to cover." In any

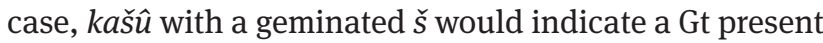
or a Gtn preterite, which does not fit well in the sequence of the Akkadian perfect forms in the other lines. Nevertheless, the Sumerian verb too is different from the other b a - prefixed hamtu verbs in the other lines.

If the verb is indeed to be understood as "cover," and if the reading of the Akkadian of the beginning of the line is correct, the meaning of the line may be understood as mourning the threshing floor which used to be filled with barley for threshing, maintained as an open and clear lot for this purpose, which is now not available for work anymore as it is covered (with dust? debris?). Nevertheless, it should be remembered that if barley is not to be read in the Akkadian, maškanu / $\mathrm{su}_{7}$ here can refer here simply to a lot or uncultivated area.

$\mathbf{1 1}^{\prime}-\mathbf{1 2}$. The verb dúb(-dúb) occurs occasionally in Emesal prayers, where it refers to smashing, and is translated by Akkadian napāșu (see Cohen 1988, 608: a+36; 615: c+208; see also CAD N/I, 285). It is possible, especially if the previous line refers to a type of labor, that smashing here refers to the smashing of barley or flax (if the latter, perhaps the first signs in the Akkadian line should be understood as [...] x kitîsu, "the ... of his/its flax"; cf. the use of the verb napāṣu for flax, as well as other materials in CAD N/I, 286b, 287b).

$\mathbf{1 3}^{\prime} \mathbf{- 1 6}$. For the possible restoration of the divine names or toponyms that were included in this litany, and for the scribal annotation in line $15^{\prime}$, see the discussion above. $\mathbf{1 7}^{\prime}-18^{\prime}$. The final verb uses a well attested Sumero-Akkadian correspondence (note that sa used here as a gloss, is also widely used as a nonstandard orthography for the nominal part of this compound verb; see Attinger 1993, 632-652). The first preserved form in the Sumerian version may possibly be understood as a precative (h é t $u$ š), which would probably indicate a different subject than the following first person form. It is less likely that $\mathrm{g}$ a $\mathrm{n}-\mathrm{t} \mathrm{u}$ š represents a cohortative verbal form ("may I sit there") since *ga-an-tuš would have been expected, in agreement with the following verb. One possibility is to read gan-tuš "tenant," usually written ga-an-tuš (see CAD A/II, 460b) (and originally deriving from the cohortative form). However, although it is possible that $\mathrm{g}$ a n- $\mathrm{t} u$ š may be used in the Ur III period and elsewhere, in most cases the reading GAN- $d a b_{5}$ is probably to be preferred; see Sjöberg (1996, 236), Heimpel (1998, 398), De Maaijer $(1999,116)$. The GAN- $d a_{5}$ worker, the etymology of which may be "may I be seized" (Heimpel 1998, 398) was a captive or "prisoner (of war)." This interpretation fits the context of our passage, which seems to describe an enemy invasion, and taking people into captivity. Admittedly, the Akkadian correspondence with amelu "man" (with the addition of -ma) does not conform to the expected șabtu "prisoner, captive."

21'. Since a litany occurs here, it would be tempting to restore the formula about skipped lines in line $15^{\prime}$ here as well, especially since the sign $\mathrm{MU}$ (which may be preserved in our line, although this is not certain) occurs in this formula. However, the signs can be reconciled with this formula only with difficulty, and in addition, the formula in line $15^{\prime}$ seems to be written in a slightly smaller and more cursive script than the Sumerian text itself, while the preserved parts of the signs in our line seem large and elaborate.

Rev. The empty lines indicate a litany, perhaps using the same divine names or toponyms as in the skipped litany on the obverse of the tablet.

\section{References}

Abusch, T. (1974): Mesopotamian anti-witchcraft literature. Texts and studies, part 1: The nature of Maqlû. Its character, divisions, and calendrical setting, JNES 33, 251-262

- (2015): The magical ceremony Maqlû. A critical edition. AMD 10. Leiden and Boston

Abusch, T./D. Schwemer (2011): Corpus of Mesopotamian anti-witchcraft rituals, vol. 1. AMD 8/1. Leiden and Boston

Attinger, P. (1993): Eléments de linguistique sumérienne. La construction de $\mathrm{du}_{11} / \mathrm{e} / \mathrm{di}$ “dire.” ОВO Sonderband. Fribourg/ Göttingen 
Bartelmus, A. (2016): Fragmente einer großen Sprache. Sumerisch im Kontext der Schreiberausbildung des kassitenzeitlichen Babylonien. UAVA 12/1-2. Berlin

Borger, R. (2005): Textkritisches zu “Mundwaschung”. Zu Walker \& Dick, Induction, BiOr. 62, 395-409

Böck B. (2003): “When you perform the ritual of 'rubbing'." On medicine and magic in ancient Mesopotamia, JNES 62, 1-16

Cavigneaux, A. (1998): Sur le balag Uruamma'irabi et le rituel de Mari, NABU 1998/2, no. 43

Cavigneaux, A./M. Krebernik (1998-2001): Nin-duluma, RIA 9, 340-341

Civil, M. (1985): On some texts mentioning Ur-Namma, Or. 54, 27-45

Cohen, M. E. (1988): The canonical lamentations of ancient Mesopotamia. Maryland

Delnero, P. (2012): The textual criticism of Sumerian literature. JCSSS 3. Boston

- (2015): Texts and performance. The materiality and function of the Sumerian liturgical corpus, in: P. Delnero/J. Lauinger (eds.), Texts and contexts. The circulation and transmission of cuneiform texts in social space. SANER 9. Boston/Berlin, 87-118

- (2016): The silence of the scribes, pt. II: An unfinished Enlil lament from Nippur, in: L. Feliu [e. a.] (eds.), The first ninety years. A Sumerian celebration in honor of Miguel Civil. SANER 12. Boston/Berlin, 77-97 (forthcoming)

De Maaijer, R. (1999): Review of B. Lafont and F. Yildiz, Tablettes cunéiformes de Tello au Musée d'Istanbul. PIHANS 77. Leiden 1996, BiOr. 56, 114-118

Durand, J.-M./M. Guichard (1997): Les rituels de Mari, in D. Charpin/J.-M. Durand (eds.), Recueil d'études à la mémoire de Marie-Thérèse Barrelet. Mémoires de NABU 4. FM 3. Paris, 19-78

Falkenstein, A. (1931): Die Haupttypen der sumerischen Beschwörungen. LSS NF 1. Leipzig

Gabbay, U. (2014a): Pacifying the hearts of the gods. Sumerian Emesal prayers of the first millennium BC. Heidelberger Emesal-Studien 1. Wiesbaden

- (2014b): A Balaĝ to Enlil from the First Sealand Dynasty, ZA 104, 146-170

- (2015): The Eršema prayers of the first millennium BC. Heidelberger Emesal-Studien 2. Wiesbaden

Geller, M. J. (2016): Healing magic and evil demons. Canonical Udug-Hul incantations. BAM 8. Boston/Berlin

Geller, M. J./J. C. Johnson (2015): The class reunion - an annotated translation and commentary on the Sumerian dialogue Two Scribes. CM 47. Leiden and Boston

Heimpel, W. (1998): The industrial park of Girsu in the year 2042 B.C. Interpretation of an archive assembled by P. Mander, JAOS 118, 387-399

Huehnergard, J. (1997): Review of GAG 3 , Or. 66, 434-444

Jaques, M. (2015): Mon dieu qu'ai-je fait? Les diĝir-šà-dab ${ }_{(5)}$-ba et la piété privée en Mésopotamie. OBO 273. Fribourg and Göttingen

Jean, C. (2006): La magie néo-assyrienne en contexte. Recherches sur le métier d'exorciste et le concept d'āšipūtu. SAAS 17. Helsinki

Kouwenberg, N. J. C. (1997): Gemination in the Akkadian verb. Assen Krebernik, M. (2006-2008): Richtergottheiten. RIA 11, 354-361

Lambert, W. G. (2007). Babylonian oracle questions. MC 13. Winona Lake.
Linssen, M. J. H. (2004): The cults of Uruk and Babylon. The temple ritual texts as evidence for Hellenistic cult practices. CM 25. Leiden and Boston

Löhnert, A. (2009): “Wie die Sonne tritt heraus!” Eine Klage zum Auszug Enlils mit einer Untersuchung zu Komposition und Tradition sumerischer Klagelieder in altbabylonischer Zeit. AOAT 365. Münster

Maul, S. M. (1994): Zukunftsbewältigung. Eine Untersuchung altorientalischen Denkens anhand der babylonisch-assyrischen Löserituale (Namburbi). BaF 18. Mainz

Mayer, W. R. (1990): Ein Ritual gegen Feindschaft im Museo Nazionale d'Arte Orientale zu Rom, Or. 59, 14-33

Mirelman, S. (2010): Performative indications in Late Babylonian texts, in: R. Pruzsinsky/D. Shehata (eds.), Musiker und Tradierung. Studien zur Rolle von Musikern bei der Verschriftlichung und Tradierung von literarischen Werken. Wiener Offene Orientalistik 8. Vienna, 241-264

Reiner, E. (1956): Lipšur litanies, JNES 15, 129-149

-(1958): Šurpu: A collection of Sumerian and Akkadian incantations. AfO Beiheft 11. Graz

Reiner, E./D. Pingree (1975): Enūma Anu Enlil Tablet 63. The Venus Tablet of Ammișaduqa. BPO 1. BiMes. 2/1. Malibu

Schwemer, D. (2006): Auf Reisen mit Lamaštu. Zum Ritualmemorandum K 888 und seinen Parallelen aus Assur, BagM 37, 197-209

- (in press): Quellen des Bösen, Abwehrrituale und Erfolgsrezepte. Möglichkeiten und Grenzen einer Systematik der babylonisch-assyrischen Magie, in: J. Kamlah/M. Witte (eds.), Zauber und Magie im antiken Palästina und in seiner Umwelt. Wissenschaftliches Kolloquium des Deutschen Vereins zur Erforschung Palästinas, November 2014. Abhandlungen des Deutschen Palästina-Vereins. Wiesbaden

Shibata, D. (2008): A Nimrud manuscript of the fourth tablet of Mīs Pî, CTN IV, 170(+188) and a Kiutu incantation to the Sun God, Iraq 70, 189-204

- (forthc.): Die Šu'ila-Gebete im Emesal. Heidelberger EmesalStudien 3. Wiesbaden

Sjöberg, A. (1996). UET 7 no. 63: A lexical text or a commentary?, ZA 86, 220-237.

Stein, P. (2000): Die mittel- und neubabylonischen Königsinschriften bis zum Ende der Assyrerherrschaft. Grammatische Untersuchungen. Jenaer Beiträge zum Vorderen Orient 3. Wiesbaden

Stola, R. (1981-82): Zu den sumerischen Entsprechungen des akkadischen Imperativs in späten zweisprachigen Texten, AfO 28, 79-91

- (1985): Zum sumerischen Prekativ in späten zweisprachigen Texten, AfO 32, 23-37

Thureau-Dangin, F. (1921): Rituels accadiens. Paris

Walker, C./M. Dick (2001): The induction of the cult image in ancient Mesopotamia. The Mesopotamian Mīs Pî ritual. SAALT 1. Helsinki

Wilcke, C. (1987): Die Inschriftenfunde der 7. und 8. Kampagnen (1983 und 1984), in B. Hrouda, Isin-lšān Bahrīyāt 3. Bayerische Akademie der Wissenschaften, Philosophisch-Historische Klasse, Abhandlungen N.F. 94. Munich, 83-120

Ziegler, N. (2007): Les Musiciens et la musique d'après les archives de Mari. Mémoires de NABU 10. Florilegium Marianum IX. Paris 